\title{
A Study on the Adjustment of Roles of Teachers and Students in Negotiated Teaching
}

\author{
Lihua Tang \\ College of Foreign Language Education \\ China West Normal University \\ Nanchong, Sichuan, China \\ Email: 16867933@qq.com
}

\begin{abstract}
Under the influence of constructivist view of knowledge, more and more teachers and scholars emphasize the use of consultation, reflection and construction. Teachers act as facilitators, negotiators, resource providers and reflective practitioners. Students are transformed into participants and creators, negotiators, collaborators, and introspection and skeptics. In the process of adjusting the role of teachers and students, we will inevitably encounter some obstacles. This article tries to find the crux of the obstacle. And the corresponding countermeasures are put forward accordingly.
\end{abstract}

Keywords: Consultation; the role of teacher and student; adjustment; teaching

Negotiated teaching is a teaching method for teachers to achieve teaching objectives through negotiation and dialogue with students based on students' cognitive basis and psychological state. It aims at changing the traditional autocratic classroom which restricts students' autonomy. It emphasizes the process of synergy between teachers and students in the teaching system. It provides a unique reference for the role change of teachers and students in the new curriculum reform. The transformation of teachers and students' roles in negotiation teaching is not achieved overnight, and it will inevitably face some adjustment obstacles. This paper attempts to explore the reasons that impede the transformation of teacher-student roles, so as to provide references for teachers to break through the traditional roles of self restriction. Finally, in view of the adjustment, this paper tries to put forward some corresponding countermeasures in order to provide some reference for the smooth transition of the role of teachers and students in the negotiated teaching.

\section{CHANGING THE ROLES OF TEACHERS AND STUDENTS: THE CHALLENGE OF NEGOTIATED TEACHING}

Negotiated teaching emphasizes the dialogue, inquiry and reflection of teachers and students as a consultative partner. It not only pays attention to develop students' ability of self constructing knowledge, but also pays close attention to the change of teachers' role as reflective practitioners. The role orientation in teaching often shows the status of teachers and students in teaching, and contains the responsibility and obligation to teaching. This has a direct impact on the effectiveness of teaching.

\section{A. Anticipation of the Role of Teachers}

As the designers and implementers of teaching activities, the role orientation of teachers directly determines the organizational form of classroom activities, which indirectly affects the position of the students. The role of teachers can be defined from the following aspects.

1) Teachers are transformed from knowledge transmitters into students' constructers of knowledge.

In negotiated teaching, teachers do not transfer knowledge directly to students like the traditional teaching paradigm, but carry out teaching activities through dialogue and consultation with students in the classroom. Cooperation, dialogue and communication between teachers and students is the main part of teaching activities Through negotiation, students constantly discover the meaning of knowledge and generate a unique understanding themselves. In this process, the teacher acts as a promoter of his own knowledge. Teachers and students participate in the teaching activities together. When students are aware of contradictions, teachers and students adopt a negotiation approach, which actively arouses students' thinking and deepens their understanding of knowledge.

2) Teachers turn from the authority of the classroom to the negotiator of learning activities.

In traditional classroom, teachers are in absolute control status. They sent instructions and instilled teaching content. The position between teachers and students is obviously in a state of inclination. It is not conducive to emotional communication between teachers and students. It is also an important reason for students' enthusiasm and learning enthusiasm. Negotiated teaching encourages teachers to change from dominator to learner negotiator. The status of teachers and students is equal. They have the right and obligation to jointly explore teaching. The development of teaching activities is a process of mutual consultation between teachers and students, and it is also an excellent time for the two sides to reach a resonance between emotion and cognition.

3) Teachers turn from the interpreters of knowledge to the providers of learning resources.

In traditional teaching interaction, when students are confused and doubtful, teachers tend to tell the answer directly. This method is not conducive to students' in-depth inquiry into the essence of the problem. Instead of saying that teachers are a kind of resources, teachers are the guides of resources, the organizers of opportunities, the guides of ideas and technical advice. 
4) Teachers turn from the instructor of the course content to the reflective practitioner.

In negotiated teaching, teachers constantly practice, reflect and reconstruct the curriculum on the basis of classroom teaching. Reflective practice is carried out throughout teaching activities. Before the beginning of teaching activities, teachers first think about building their own understanding of the curriculum. In the process of teaching activities, teachers pay close attention to the state of students. Teachers constantly reflect on the problems raised by students and apply appropriate teaching methods to find the best way to deal with them. They constantly adjust the teaching methods and teaching procedures. After the teaching activities, the teachers re - review the teaching process, and summarize the teaching experience and deficiencies, actively reflect on the causes and improvement methods, and carry out the accumulated experience for the next consultation teaching activities.

\section{B. Requirements for the Role of Students}

When the teacher's role changes, it will inevitably cause the corresponding change of student's role. Clarifying the role of students helps teachers to adopt appropriate teaching behaviors and promote effective interaction between teachers and students. The role of students in negotiation teaching needs to meet the following requirements.

1) Students are participants and creators of the course

In negotiated teaching, the student is transformed from the receiver of knowledge into the participant and creator of the course. Students are no longer confined to mechanical memory of knowledge. They begin to explore curriculum content based on practice. They constantly explore the connotation of knowledge and find the real value of curriculum. In the process of constant reflection and exploration, teachers and students are self constructing and enriching the course content through negotiation. As a member of negotiation, teachers will help students create curriculum in the teaching process.

2) The student is the negotiator of the teacher's teaching

In traditional classroom teaching, there are occasional group cooperation opportunities among students, but cooperation between teachers and students is very rare. Negotiated teaching breaks through the fetters of traditional teachers and students' role concept and advocates a democratic way to promote teacher-student mutual assistance in the real sense. In the negotiation class, students have full freedom of expression and protection of rights. In the whole teaching process, the teachers and students start consultations around the teaching content. Curriculum is no longer opposed to students, but is intermingled with life experience and survival experience, thus creating new meaning and value.

3) Students are the introspectors and doubters of the teaching results.

In traditional classroom teaching, students generally believe in teaching achievements. And take this attitude as the ultimate goal of learning. However, students in negotiated teaching must have the quality of questioning and reflecting. Textbooks and teachers are no longer absolute truths. Only the teaching results that have been tested by practice are reliable. Dares to question teaching achievements, means that the authority of teachers is no longer an invisible fetter restricting students' freedom. True authority is not born, but needs to be verified by its own strength. Students' reflection and questioning on teaching achievements are the driving force for deepening teaching reform.

\section{II.BREAK THROUGH THE BARRIER OF ADJUSTMENT AND ADJUSTMENT: THE BASIS OF CONSULTATION TEACHING}

In the negotiated teaching, the adjustment and transformation of the role of teachers and students is a great challenge for teachers. Habits and personality factors are not formed in a short time. There must be obstacles in the adjustment of new and old roles. Only by finding the crux of the problem can we ensure the effective implementation of the consultative teaching.

\section{A. The Traditional Teacher and Student Role View}

For a long time, the teaching structure has always been teacher centered. Teachers appear in the classroom as an authoritative person. As recipients, students act as containers for teachers' instilling teaching. With the development of the times, this form of teaching view is obviously unable to meet the needs of the modern society for the compound high and new talents. However, teachers have already established their own role recognition, and accordingly form a fixed teaching behavior. Under the background of exam oriented education, the old concept of teacher student role is not at stake. It is not easy for a teacher to really change his role concept.

\section{B. Teachers' Lack of Theoretical Knowledge}

In China, the research on negotiated teaching is still in its early stage. Many teachers lack the understanding of the connotation, significance and practice of this teaching mode. They are in the smattering of the meaning of negotiation teaching, the advantages of negotiation teaching and the specific procedures for their implementation. Part of the reason is that negotiation teaching is not enough to promote publicity. The more important reason is the weak theoretical foundation of teachers themselves. Traditional teaching demands not too high on the basis of teachers' teaching theory, but usually only at the level of practical experience. Besides, teachers have been influenced by the traditional authoritative teacher and student role concept for a long time, and they are not willing to break the old mode. This is bound up with the lack of educational theoretical knowledge.

\section{The Restriction of Teaching Inertia}

In the long term teaching process, teachers gradually form a unique teaching style and form a set of fixed teaching habits. In the meantime, it contains personal cognition of teaching. Negotiation teaching focuses on power sharing between teachers and students in classroom teaching. Teaching breaks through the situation of teachers' independence in traditional teaching, and advocates students' equal consultation with teachers in the 
questioning thinking. This is a great challenge for teachers. However, the teaching experience that teachers accumulate over a long period of time makes them comfortable with the status quo. To relax in the reform of teaching concept, teaching is closed to a certain extent. Although some teachers are willing to accept new teaching ideas, teaching inertia makes it difficult for them to take a substantive step Reform can easily fall into an awkward situation. In addition, teaching experience does not bring too much deficiency to teachers, but is more handy. This makes the emotional state of teachers more conservative. This inertia of teaching indirectly affects the switch of the new role of teachers and students, and becomes another major difficulty in the implementation of negotiation teaching.

\section{The Obstruction of the Evaluation}

The talents advocated by the new curriculum reform should be equal to knowledge and ability, emotional attitude and values, and must have lifelong learning ability. However, learning ability is an abstract concept and cannot be measured in a quantitative way, which makes it difficult to evaluate accurately. Therefore, students' academic achievement is still a major indicator of teachers' teaching ability. Accordingly, teachers' pursuit of grades is more than enthusiasm for teaching reform. It is easy for them to neglect the cultivation of students' learning ability. And they just pay attention to the scores on the test paper. Under the background of exam oriented education, this score evaluation mechanism has greatly hindered the transformation of the new teacher's role view. Old teaching ideas still exist in the minds of teachers. The objective problem of teaching evaluation mechanism has become one of the important factors that obstruct the change of teachers and students' role.

\section{EFFECTIVE COPING STRATEGIES: THE KEY TO THE IMPLEMENTATION OF CONSULTATIVE TEACHING}

Breaking through the fetters of traditional teacher and student roles is the key to the successful implementation of negotiated teaching. The change of teacher's role can make this better, thus helping to promote the smooth progress of classroom teaching reform.

\section{A. Change the Concept and Position the of Teachers and Students}

In consultated teaching, the reconstruction of the role of teachers and students is a breakthrough point which is different from the traditional teaching model. Traditional teaching emphasizes the relationship between authoritative and controlled teachers and students. That leads to make teaching as a means of instillation of knowledge. Students and teaching are controlled by the mode of expert courses, and they lose the right and freedom to grasp the curriculum. Consultative teaching is a good remedy for this defect. Students are participants and creators of the course. Teachers are reflective practitioners. Both are in an equal position in the classroom. Students' participation makes the classroom more lively. At the same time, students are also in the state of arousal and stimulation, and they will explore the meaning of knowledge initiatively. They are free to participate in innovation. At the same time, teachers' Reflection on curriculum is actually equivalent to the process of curriculum self construction. Every student is a unique individual. In consultation teaching, the dialogue and cooperative relationship between teachers and students makes teachers have to understand the students' unique ideas and change the language and behavior of the traditional teaching. Only when teachers truly agree with each other from the heart, can the new role concept of teachers and students be truly established.

\section{B. Attach Importance to the Theoretical Accomplishment and Broaden the Horizon of Teaching}

In negotiated teaching, many ideas are quite different from those advocated in traditional teaching. Teachers and students share equal opportunities in teaching activities and implement rights sharing. Only by attaching importance to the improvement of teachers' theoretical quality and actively guiding their participation in teaching, can the idea of consultative teaching be deeply rooted in the hearts of the people. On the one hand, teachers should take the initiative to learn the theoretical knowledge of education and pay close attention to the latest theoretical trends of curriculum and teaching in the near future. On the other hand, teachers should constantly internalize educational theories and actively apply them to teaching activities according to their own actual conditions. Teachers should actively cultivate scientific research consciousness and jump out of the traditional teaching thinking set. Teachers should be bold enough to be teaching researchers instead of regular instructors. The times are always improving, and the teaching idea is upgrading. Only by actively trying out the new teaching paradigm can we realize the professionalization of teachers and the deepening of teaching reform.

\section{Advocating Practical Reflection and Breaking through Teaching Habits}

Under the traditional teaching paradigm, teachers are accustomed to teaching according to their own long established teaching mode. They seldom notice the loopholes and deviations in their teaching, that is, the lack of reflection. Reflection is not simply a summary of teaching activities. The teachers ponder deeply on his teaching activities and analyze the causes, strategies and Strategies of teaching behaviors, decisions and results. Effective teaching reflection can improve teachers' practical level and promote their action and theoretical level. Negotiation teaching is a clear requirement for teachers as reflective practitioners. Teachers must bear their own responsibility for teaching. In the whole process of teaching implementation, they should carry out teaching reflection in time. Reflection before class means that teachers should build their own understanding of the curriculum. Reflection in class means that teachers pay close attention to students' situation and deal with teaching events in time and adjust teaching procedures. After class reflection is to clarify the meaning and experience of classroom experience, and accumulate experience for the next negotiation teaching. This requires teachers to dare to 
break through the role limitation of teaching habits. They use new thinking to face their role, and take practical action to restructure the curriculum.

\section{Improving the Evaluation Mechanism and} Strengthening the Internal Drive of Reform

At present, teaching evaluation in China is still dominated by quantitative evaluation criteria. This mechanism is deeply rooted in the concept of fractional supremacy. The limitation of the evaluation mechanism is not conducive to improving the enthusiasm of teachers' development and students' learning ability. Therefore, the teaching evaluation mechanism should be diversified from single to single. We should not only emphasize the mastery of knowledge points, but also increase the assessment of students' learning ability. The improvement of teaching evaluation mechanism should better meet the requirements of the new curriculum reform in an all-round way. In addition, in consultation teaching, the teachers and students adopt the negotiation method to carry out the teaching evaluation and fully respect the rights of both teachers and students. They make the results more objective and impartial. Improving the evaluation mechanism can promote the smooth development of teaching reform. More and more new teaching models will appear in large numbers, thus increasing the activity of the whole teaching system. The driving force of teaching reform has been greatly enhanced, thus promoting the continuous evolution and innovation of the whole teaching reform.

\section{ACKNOWLEDGEMENT}

The paper was supported by the research project of Sichuan foreign language and Literature Research Center in 2017 (No. SCWYH17-20)

\section{REFERENCES}

[1] Aijun Liu, 2009, Research on listening and speaking teaching mode in Multimedia Network Environment [J], foreign language world

[2] Dingfang Su, 2013, Comprehensive curriculum objectives and quality of English Majors -- a review of the third foreign language teaching competition held by the foreign teachers' Association Cup in China J , Foreign Language World

[3] Dingfang $\mathrm{Su}, 2012$, College English teaching competition and teacher development $[\mathrm{J}$, Foreign Language W

[4] Kefu Lang, Wangling,2 010 , Research on the motivation of autonomous learning under the Internet Teaching Model $[\mathrm{J}]$ Foreign Language World

[5] Liuheng, Zhen Zhinian, 2008, Study on English Listening Classroom Teaching of Higher Vocational Students' negotiating [ J ] Journal of Jixi University

[6] Liu Yichun, 2002, the case study between LHAs and LLAs in strategies using, Foreign Language World

[7] Liu Ruiqing, 2003. Psychology for Language Teachers: A Social Constructivist Approach. Beijing: Foreign Language Teaching and Research Press.

[8] Xuehui Liu, 2005. Second language acquisition in a classroom setting: theoretical frameworks and analytical units [J],'Foreign Language and Foreign Language Teaching

[9] Xuehui Liu, 2007. Negotiation, interaction and timely output: a timely exploration of classroom language [J]Foreign Language and Foreign Language Teaching
[10] Zhu, Yuan. 2005. Language Learning Strategy Instruction with English Majors: a Study in the Chinese Context. Unpublished doctoral dissertation, Shanghai International Studies University, Shanghai. 